\title{
University spin-off's performance: Capabilities and networks of founding teams at creation phase
}

\author{
Thanh Huynh", Dean Patton ${ }^{\mathrm{a}}$, Daniel Arias Aranda ${ }^{\mathrm{b}}$, Luis Miguel Molina Fernández \\ ${ }^{a}$ Leadership, Strategy and Organisations Department, Faculty of Management, Bournemouth University, 89 Holdenhurst Road, \\ Bournemouth, BH8 8EB, United Kingdom \\ ${ }^{b}$ Department of Business Administration, Faculty of Economic and Business Sciences, University of Granada, Granada 18071, Spain
}

\begin{abstract}
The extant literature highlights that environmental conditions, during the creation phase, imprint on a startup's survival and growth. However, there are few studies that explore the composite nature of a founding team's capabilities and networks, developed within this phase, and the contribution made to future performance. This paper uses the distinctive context of university spin-offs, where early stage ventures are fostered by institutional interventions, to analyse the influence that the capabilities and networks of a founding team, at incorporation, have upon the future performance of the spin-off. Based on data from 181 university spin-offs, this paper empirically demonstrates that the entrepreneurial capabilities of a founding team, augmented during the 'creation' phase, have a positive influence on the performance of a spin-off during the 'growth' phase, and that the networks of a founding team indirectly affect a spin-off's performance through the enhancement of a team's entrepreneurial capabilities.
\end{abstract}

Keywords: University spin-offs; founding teams; entrepreneurial capabilities; networks; incubation 


\section{Introduction}

University spin-offs have received increasing attention from academia, governments, and policymakers because they not only generate new innovations, productivity, and jobs in regional economies (Hayter, 2013) but also make a significant contribution to university productivity and creativity (Urbano \& Guerrero, 2013). A university spin-off has been defined as a new venture founded by current students or faculty members of a university to develop and exploit their ideas based on an entrepreneurial process (Smilor et al., 1990); subsequently this process has been broken down into a number of phases (see Shane, 2004a; Vohora et al., 2004a; Lockett \& Wright, 2005; Rasmussen et al., 2011). For the purposes of this paper we identify two phases 'creation' and 'growth'. 'Creation' is the period up to incorporation and includes idea generation, 'proof of concept', setting out a business plan for commercialisation and the formation of a team charged with its execution. The 'growth' phase is the period after incorporation that sees the introduction of products/services and their subsequent entry and positioning within a market.

While the capabilities and networks of entrepreneurial teams have been discussed in the literature (Walter et al., 2006; Eisenhardt, 2013; Lundqvist, 2014) such issues have not been analysed in the context of university spin-offs (Gonzalez-Pernia et al., 2013). University spin-offs can have similar characteristics to other new ventures, but they face a fundamentally different set of challenges due to the context in which they are created (Vohora et al., 2004a). The founding teams originate from a non-commercial environment where sophisticated technical capabilities are valued and fostered; often at the expense of commercial understanding that could help facilitate the exploitation of ideas (Clarysse \& Moray, 2004). A university spin-off is therefore characterised by highly innovative products/services that are often new and unique to the market (Heirman \& Clarysse, 2004). However the performance of these spin-offs is poor, compared to other new ventures, because the founding teams have to deal with complex tasks in unfamiliar and uncertain business environments (Shane, 2004a) which is further exacerbated by their limited industrial experience and/or access to non-technical networks (Cooper \& Daily, 1997). To offset these limitations the university sector will often provide ideas with commercial potential 
a supportive environment via a technology transfer office (TTO) and in some cases incubation facilities (Clarysse \& Moray, 2004). Such interventions lead to an artificial time lag between idea generation and company formation; creating an opportunity to fine tune the idea and explore possible changes to the structure and composition of the founding team before incorporation (Vanaelst et al., 2006). Changes to the structure are necessary because the technological founders, typically, exhibit less commitment to the commercialisation of the idea, have lower growth aspirations (Clarysse \& Moray, 2004; Vanaelst et al., 2006) and view themselves more as part-time entrepreneurs (Müller, 2010). The time lag, therefore, provides an opportunity when possible weaknesses in the founding team of the university spin-off can be addressed through the introduction of individuals with more commercial experience, particularly in the market segments targeted by the spin-off (Vohora et al., 2004b; Filatotchev et al., 2006). The extant literature on the development of start-ups, while identifying the contribution of enhanced networks and capabilities to a ventures development, does not address the underlying factors that facilitate such enhancement. In the context of university spin-offs, with the acknowledged commercial limitations of academic founders, this paper posits that the quality of the founding team, identified by its networks and capabilities at incorporation, significantly influence a spin-off's future performance.

Hence, this paper addresses two questions; whether the capabilities of founding teams at incorporation influence the future performance of university spin-offs and if networks, accessible at this time to founding teams, contribute to this process. The analysis of the capabilities and networks of founding teams is undertaken in the 'creation' phase up to incorporation and this is assessed against the performance of spin-offs in the 'growth' phase, post incorporation. To analyse entrepreneurial capabilities the constructs of technology, strategy, human capital, organizational viability, and commercial resources are employed through the lens of the resource-based view (Barney, 1991). In addition, the analysis also considers the contribution of networks to the development of entrepreneurial capabilities and examines the nature of this relationship based upon the structure, governance and content of the constituent elements of such networks (Tsai \& Ghoshal, 1998; Amit \& Zott, 2001; Hoang \& Antoncic, 2003; Newbert \& Tornikoski, 2013). This analysis is employed to develop and 
test a theoretical framework, which uses imprinting theory (Marquis \& Tilcsik, 2013) to propose that the capabilities and networks of founding teams influence the performance of university spin-offs beyond incorporation. The results presented are based upon a sample of 181 Spanish university spin-offs based in 35 universities across all regions of Spain; each spin-off was created and developed by a founding team and responses were obtained from a member of each team. The findings indicate that the capabilities of founding teams have a direct affect upon the performance of spin-offs' and that the networks of founding teams have an indirect influence through their impact on the capabilities of the founding teams.

\section{Literature review and theoretical framework}

University spin-offs are often conflated with other technology or research-based start-up ventures as they share common characteristics and face similar difficulties in establishing market legitimacy and mobilizing their growth potential (Zahra et al., 2007). However, it is argued that they are distinctive from a broader category of technology start-ups, or start-ups in general, due to certain characteristics. University spin-offs usually involve the development of a business opportunity based on novel and potentially disruptive technology or tacit knowledge emerging from academic research (Ardichvili et al., 2003; Markman et al., 2008; Rasmussen et al., 2011); the early founders, therefore, originate from a non-commercial environment and often lack the skills and resources necessary to facilitate the commercialisation process (Hayter, 2011). To improve their commercial skill set spin-offs, from an early stage, are more likely to engage a broad range of stakeholders (academic inventor, the university, the founding team, and equity investors) with diverse requirements; thus increasing the potential for conflicting objectives (Boardman \& Ponomariov, 2009; Colombo \& Piva, 2012). Therefore, while start-ups per se face liabilities of newness (Stinchcombe, 1965), it is suggested that these contextual issues intensify such problems and negatively impact upon a university spin-off's ability to reach the growth phase (Vohora et al., 2004a). This increases their reliance upon the reputation of the host university or its TTO/incubator (Pries \& Guild, 2007) and leads Rasmussen et al. (2011, p. 1315) to argue that the examination 
of the 'genesis and early development' of university spin-offs can offer insight into how they build a distinctive resource base that supplies the necessary credibility in fast moving markets.

\subsection{Imprinting theory and university spin-off's performance}

To examine the impact that the capabilities and networks of early stage spin-offs have upon the ventures ability to grow, this paper employs imprinting theory. Imprinting is defined as "a time-sensitive (occurring at sensitive stage of life) learning process (a stamping process whereby the focal entity reflects elements of its environment) that initiates a development trajectory (i.e., produces persistent outcomes)”' (Mathias et al., 2015, p. 12). Within the entrepreneurship context, imprinting research posits that early founding conditions - resource endowments, collaborations, and other internal and external factors - have a lasting impact on the future outcomes of a new venture (Sapienza et al., 2006; Ganco \& Agarwal, 2009; Milanov \& Fernhaber, 2009). As Rasmussen and Wright (2015) indicate a spin-off in the early formative stages will rely heavily on university resources and decisions made in this period are likely to have a long lasting effect on future venture development. In other words, "as for a child, the conditions under which an organization is born and the course of its development in infancy have important consequences for its later life” (Kimberly, 1979, p. 438). Thus, university spin-offs can be said to be imprinted by the conditions of "groups, institutions, laws, population characteristics, and sets of social relationships that form the environment of the organization” prevalent at the creation phase (Stinchcombe, 1965, p. 142). While a number of researchers argue that the networks and resources embedded within a founding team quickly dissipate after a new venture is created (Brüderl \& Schüssler, 1990; Shane \& Stuart, 2002), this conflicts with other research that suggest such factors, with the help of university support, can address inherent weaknesses in spin-off formation and facilitate growth ambitions (Kakati, 2003; Heirman \& Clarysse, 2004; Lockett \& Wright, 2005; Agarwal \& Chatterjee, 2007; Bathelt et al., 2010; Soetanto \& van Geenhuizen, 2015). It is therefore important to understand the process by which networks and capabilities that originate with the founders evolve through interactions with the university, before incorporation, and the impact this imprint has on the growth phase of a spin-off. 


\subsection{Hypotheses Development}

\subsubsection{Capability development}

Research suggests that founding teams need to exploit resources embedded within their networks to support the growth and development of spin-offs (Shane, 2004a; Vohora et al., 2004a; Walter et al., 2006). However, academic founders originate from non-commercial environments and are constrained by relatively insular networks that provide limited access to individuals from industry integral to spin-off development (Mosey \& Wright, 2007). Broadening the scope of networks is problematic as academic founders lack legitimacy with potential industry partners (Stinchcombe, 1965; Zahra et al., 2007) and relationships created, under such conditions, are characterised by resource dependency and asymmetric power that limit a spin-off's ability to broker advantage. This is of concern as, where good industry links exist, a variety of resources (ideas, market information, problem solving, social support, and financial resources) are available (Shane \& Cable, 2002; Hoang \& Antoncic, 2003; Mosey \& Wright, 2007) which increase a spin-off's ability to exploit new opportunities, enter new markets, or sell new products or services in existing markets (O'Gorman et al., 2008; Tolstoy \& Agndal, 2010; Hayter, 2013). It is therefore important that, prior to incorporation, university spinoffs combine with technology transfer officers to take advantage of endowments available from the host university to strengthen social capital, increase legitimacy and broaden potential networks (Shane \& Stuart, 2002; Clarysse et al., 2007; Geuna \& Muscio, 2009). Accordingly, this study posits that within the university spin-off process, between the creation of a research idea and the incorporation of the business, the networks of a founding team undergo transformational change. This change is a consequence of TTO/incubator support that addresses weaknesses in commercialisation and legitimacy through the introduction of new team members with relevant skill sets and legitimacy that facilitates access to a wider range of network partners. This, more diverse, founding team becomes imprinted within the spin-off improving access to capabilities through the new team members and the networks they can access 


\section{H1. The founding teams of university spin-offs improve entrepreneurial capabilities by the}

\section{exploitation of their networks.}

\subsubsection{Capabilities}

The process of mobilizing resources from external sources is an important task in the entrepreneurial process (Aldrich \& Martinez, 2001), and it has been suggested that founding teams may access critical resources at below-market cost thanks to their relationships with resource gatekeepers (Hite, 2005; Newbert \& Tornikoski, 2013). The type and quality of such resources characterise the content of networks (Amit \& Zott, 2001). Resource types can be tangible or intangible in nature and include ideas, strategic advice (Deakins, 1996; Yli-Renko et al., 2001), access to financial providers (Rothschild \& Darr, 2005; Kitagawa \& Robertson, 2012), technology (Lockett \& Wright, 2005), appropriate staff (Tolstoy \& Agndal, 2010) and emotional support (Gimeno et al., 1997; Rasmussen \& Wright, 2015; Soetanto \& van Geenhuizen, 2015). However, the transition from a research idea within a university context to a commercial opportunity creates distinct challenges for university spin-offs (Vohora et al., 2004b; Zahra et al., 2007). As a consequence, knowledge about new venture creation in other contexts maybe less applicable (Rasmussen \& Wright, 2015) and university spin-offs may need to build more bespoke entrepreneurial competencies that facilitate the commercialisation of research ideas (Rasmussen et al., 2011). In the case of spin-offs, the social capital of a university can often confer security and scientific credibility that enables access to a range of resource gatekeepers (Newbert \& Tornikoski, 2013) and their commercial knowledge and capabilities (Zucker et al., 2002; Patton \& Marlow, 2011; Kitagawa \& Robertson, 2012). Such university support, particularly in the earliest stages of spin-off development, can alleviate some of the problems associated with resource scarcity (Rasmussen \& Wright, 2015). It is therefore important that, prior to incorporation, within the context of university spin-offs, that technology transfer officers combine the endowments from academics with the host university’s resources and social capital to strengthen the capabilities of the new entity (Shane \& Stuart, 2002; Clarysse et al., 2007; Geuna \& Muscio, 2009; Huynh, 2016). Combining resources and networks in this way has the potential to improve leadership, offer access to 
funding streams and enhance managerial, technology and commercial skills (Helfat \& Peteraf, 2003); positioning a firm on a different growth trajectory (Shane \& Stuart, 2002). We, therefore, analyse the impact of capabilities available at incorporation on the development of the spin-off in the growth phase.

\section{H2. The entrepreneurial capabilities of founding teams at the creation phase positively impact} spin-off performance in the growth phase.

\subsubsection{Network impact}

While it is known that the networks of new ventures evolve to broaden the range of partners, potentially increasing the access to resources and skills that support development (Witt, 2004), there is limited evidence that evaluates the influence that a founding team's networks, at incorporation, exerts upon future spin-off performance. It is argued that the networks of founding members are imprinted within the networks of post spin-off firms (Butler \& Hansen, 1991; Kakati, 2003; Agarwal \& Chatterjee, 2007). In particular, the entrepreneurial network evolution models (see Butler \& Hansen, 1991; Hite \& Hesterly, 2001) show that the networks of founding teams, develop from social (identity) networks in the 'creation' stage of the firm to, more strategic, business focused (calculative) networks in the 'growth' phase. However it is not suggested that, as new networks develop, previous linkages are severed; consequently previous connections can play an important role in how the network evolves. Eisenhardt and Schoonhoven (1996) indicate that awareness plays a central role in the establishment of relationships and these relationships can be leveraged to increase awareness of the spin-off and its capability; the networks of founding teams therefore raise a spin-off's opportunities to form new connections and create a path dependent network environment that shapes its network trajectory (Milanov \& Fernhaber, 2009). With the support of the TTOs the majority of university spin-offs are developed by teams, created to address weaknesses in the industry and entrepreneurial experience of the academic entrepreneurs (Clarysse \& Moray, 2004; Mosey \& Wright, 2007) and enhance performance (Visintin \& Pittino, 2014).

The networks of a spin-off in the 'growth' phase, thus, are a hybrid that includes the pre-existing social links of a founding team and the new connections that emerge as it grows (Milanov \& Fernhaber, 2009). This 
paper suggests that the identity networks of the founding team support the development of later calculative networks as they provide an important source of access and legitimacy integral to network improvement and maturity. These synergistic effects have a positive impact upon the final performance of the spin-off, which leads us to specify hypothesis 3.

\section{H3. The networks of founding teams at the creation phase positively impact spin-off performance in the growth phase}

\section{Insert Fig. 1 about here.}

\section{Empirical study}

From 1988 the Spanish government established policy to encourage the establishment of university offices for the transfer of research results (OTRI) with the purpose of commercialising technology that had evolved from research. While there are contextual differences with reference to the levels of governmental support, the principle aim and the processes undertaken by TTOs within universities are similar to those that exist in other European countries (Berbegal-Mirabent et al., 2013). OTRI's engage in a wide range of research and development activities but only 35 are involved in the creation and development of spin-offs; embedded in the sector they are recognised as an important source of fine-grained information about university spin-offs in Spain. Through their offices we were able to build a dataset of 862 spin-offs, created by teams, which still retained at least one academic member from a university. These spin-offs were subsequently surveyed using a web-based instrument; this survey was undertaken in the summer of 2012 and resulted in 181 responses, 21 per cent of the research population. In each spin-off there was one respondent from the founding team that, at the time of the survey, held a position on the executive board and had been an active member of the senior management team from the outset. The majority of spin-offs, 98 percent, were created after 2003 inside a university incubator and operated in a variety of sectors (see table 1). Within the survey, to ensure the content validity of measurements, a seven-point Likert scale was employed using constructs from existing entrepreneurship and management studies (Tsai \& Ghoshal, 1998; Antoncic \& Hisrich, 2001). The survey is in 
two parts, the first part required a respondent to self-report on a founding team's capabilities and networks before incorporation; the second part provided self-reported information on the current performance of the spinoff based on financial and non-financial criteria (see appendix A and B).

\section{Insert Table 1 about here.}

\subsection{Measures for the independent variables of networks and capabilities}

To test these hypotheses a range of measures have been developed from the extant literature to examine the independent variables of networks and capabilities. To assess the perceived quality of a founding team's network prior to incubation, eight measurements across three dimensions: structure (ties, density and centrality), governance (reputation, reciprocity and trust), and content (quality and diversity of information) (Amit \& Zott, 2001; Hoang \& Antoncic, 2003) are employed. For structure, ties were measured by constructs that investigate the willingness to engage in social, political, and family discussions (Marsden \& Campbell, 1984; Parks \& Floyd, 1996); density by a three-item scale that evaluated interactions within networks (Marsden, 1993) and centrality was based on the location of actors within information flows using four questions that assessed how respondents communicated with others within networks (Rowley, 1997). In terms of governance, reputation was identified from responses to criteria established by Uzzi (1996) and Shane and Stuart (2002); reciprocity by four questions that established the level of support received, the accumulation of favours, and perceived fairness in relationships among members (Miller \& Kean, 1997) and trust by four questions in which respondents rank the trustworthiness of other members within the network (Tsai \& Ghoshal, 1998). To measure content, the quality of information was judged by the accuracy, relevance, reliability, specificity, and timeliness of information (O'Reilly III, 1982) and diversity by the availability of business relevant data; broken down into market data, product and process design data, marketing know-how, and packaging design or technology data (Gupta \& Govindarajan, 2000) (see appendix B).

The capability construct is derived from previous research (McGrath, 1997; Antoncic \& Hisrich, 2001; Lumpkin \& Dess, 2001) and employs measures for technology, organizational viability, human capital, strategy, 
and the commercial resource of founding teams. For technology, respondents answered six questions about the ease of imitation, scope, continuity, and the market signals for their technology (McGrath, 1997). Organizational viability, measurements were adapted from studies of Leonard-Barton (1992), Zahra (1993) and Antoncic and Hisrich (2001) to construct five questions appertaining to internal communication mechanisms, formal control mechanisms and organizational support within founding teams during the creation period. A four-item measurement tool, adopted from the studies of McKelvie and Davidsson (2009) and (Ganotakis, 2012), was used to measure human capital through evidence of industrial, managerial knowledge and work and entrepreneurial experience of the founders. The strategy measurement employed questions that investigated levels of innovation, proactiveness, risk-taking, and competitive aggressiveness among the founding team (Covin \& Slevin, 1989; Lumpkin \& Dess, 2001). Finally, four questions based on the customer relationship, commercial and marketing process design, and staff's training, were used to measure the commercial resource available within the founding team (Powell \& DentMicallef, 1997; Nadherny, 1998) (see appendix B).

\subsection{Measures for the dependent variable performance}

Traditionally, measurement of the dependent variable, performance, has emphasised financial growth indices (Chandler \& Jansen, 1992; Murphy et al., 1996; Kathuria, 2000), represented by an increase in sales or return on net assets (Chandler \& Hanks, 1993; Garg et al., 2003). Increasingly, however, it has been advocated that multi-dimensional performance measures are required, particularly in the context of early stage new ventures, where access to financial information is highly problematic (Wiklund, 1999; Ittner \& Larcker, 2003; Wiklund \& Shepherd, 2005; Campbell, 2008). This has led to the inclusion of non-financial measures as a complementary factor, for example activities concerning the operations and marketing of the firm (Higashide \& Birley, 2002). Thus, to understand the performance of a university spin-off after incorporation, this study employed financial, operational (Westerberg \& Wincent, 2008), and market performance measures (Murphy et al., 1996; Ittner \& Larcker, 2003). Financial performance was measured using a firm’s growth in terms of sales revenue, and net profit margin; operational performance using product/service innovation, process of 
innovation, and adaptation to new technology, and market performance using product/service quality, product/service variety, and customer factors (see appendix B).

\subsection{Control variables}

A number of control variables were employed and the survey requests each respondent to identify that they are a member of a spin-off's founding team, to identify their roles within the spin-off and to confirm that at least one person from the founding team worked at the university at the time the spin-off was established. To manipulate for the potential negative effect on the performance of a spin-off created outside a universities' incubator, this study will include a dummy variable coded one if the spin-off was created inside the parent incubator and zero otherwise. Moreover, we consider the age and regions of a spin-off as a control variable that can influence its performance.

\section{Analyses and results}

Structural equation modelling (SEM) is used to test the research hypotheses. This entails a twostage approach; a measurement model using confirmatory factor analysis (CFA) to examine the validity and reliability of measurements, and a structural model to test the relationships among latent variables (Anderson \& Gerbing, 1988; Shook et al., 2004; Byrne, 2010). This two-stage process begins with a finegrained exploration using linear regression analysis to understand the contributions that the networks and capabilities of founding teams have on each aspect of university spin-off performance, and ends with a mediation model construct.

The research employs CFA based on the maximum likelihood method as the normality test revealed that all of the observed variables have significant kurtosis and skewness p-values, and the relative multivariate kurtosis is within an acceptable range (1.036). While the sample size of 181 is above the minimum requirement of 150 observations recommended by Muthen and Muthen (2002) for the deployment of CFA, it is recognised that a goodness-of-fit (GFI) test (Barrett, 2007) must be used where 
fewer than 200 observations are in evidence. To address this issue a combination of the ratio chi-square/degrees of freedom (CMIN/DF<3), RMSEA (<0.08), GFI (>0.9), NFI (0.9), and CFI (0.9) was employed to test the model (Ping Jr, 2004).

To reduce common method bias, previously validated measurements were employed (Spector, 1987) and a pilot test on five spin-offs from the university of Granada was undertaken to help fine-tune the survey instrument. There is a potential error generated by the use of self-reporting from respondents especially as many of the measures are complex in nature and require post-hoc assessment. To reduce this issue, Harman's onefactor test was employed on all variables and the results (33.79) suggest that the relationships among entrepreneurial capabilities, networks and spin-off performance, in this study are unlikely to be caused by common method bias. To avoid measurement errors, the study conducted proper survey measures and used a construct validation test (the empirical indicators actually measure the construct) for validity (convergent and discriminant) and reliability. The results prove that the research measurements used were both valid and reliable (see appendix B).

\section{Stage 1: Measurement model}

The results from a fine-grained analysis (Table 2) suggest that the relationship between networks and performance is somewhat complex. The results show that a founding team's network structure, at incorporation, has a negative influence on both financial $(-0.428, p=0.068)$ and operational performance $(-0.111, p=0.043)$, that network governance has no influence on any aspect of performance and that structure, governance or content have no impact on market performance. In contrast, the results for network content show a positive imprint on the financial performance exhibited by a university spin-off $(0.5789, p=0.016)$. The results appertaining to the capability construct of a spin-off are more categorical. The commercial resources available

to a founding team at the creation phase are likely to generate positive influences on all aspects of spin-off performance: financial $(0.180, p<0.001)$, operational $(0.153, p<0.001)$, and market $(0.260, p<0.001)$ and the technology and organizational viability of a founding team also indicate a positive influence on operational 
performance $(0.141, p=0.002)$ and market performance $(0.247, p=0.006)$ respectively. However, unexpectedly, the variables of human capital and strategy had no impact on the financial and operational performance and a negative influence on the market performance of university spin-offs $(-0.097, \mathrm{p}=0.01 ;-0.274, \mathrm{p}=0.032)$.

\section{Insert Table 2 about here.}

We construct a measurement model by estimating the second-order factors (networks and entrepreneurial capability) and the covariance among those new variables and a spin-off's performance. The result suggests that the measurement model is good fit (CMIN/DF=1.537, RMSEA $=0.055, \mathrm{NFI}=0.962, \mathrm{CFI}=0.986, \mathrm{GFI}=0.951)$ and all first-order variables significantly $(\mathrm{p}<0.001$ ) load on second-order factors. Thus, the measurement model is valid to construct a structural model for hypothesis tests.

\section{Stage 2: Structural model}

Fig. 2 shows that the direct path between networks and entrepreneurial capabilities is positive and significant $(0.340, p<0.01)$ indicating that the founding teams of university spin-offs build up their entrepreneurial capabilities during the creation phase by the enhancement of founding teams via the introduction of personnel with wider industrial experience and more commercial networks; offering support for hypothesis 1. The findings also provide support for hypothesis 2 and evidence that the entrepreneurial capabilities of a founding team prior to incorporation positively influence future spin-off performance $(0.466$, $p<0.01)$. However, the relationship between the networks of a founding team and its spin-off's performance is not significant (-0.081, $\mathrm{p}>0.01$ ) which leads to a rejection of hypothesis 3 (Fig. 2).

\section{Insert Fig. 2 about here.}

To understand how founding teams can exploit networks to improve entrepreneurial capabilities and enhance spin-off performance, the indirect paths of the research model have also been analysed. Consistent with hypothesis 1 , networks appear to influence positively and significantly entrepreneurial capabilities $(0.340$, $p<0.01$ ). The findings show that networks are likely to exert a strong influence on organizational viability 
(0.322, $p<0.01)$, strategy $(0.297, p<0.01)$, and commercial resource $(0.285, p<0.01)$ but have a more limited effect on the technology $(0.232, p<0.01)$ and human capital $(0.099, p<0.01)$ of founding teams. Furthermore, networks have a significant and positive indirect effect on a spin-off's performance $(0.158, p<0.01)$ (Table 3$)$. In other words, networks positively influence a spin-off's performance through a mediate factor (entrepreneurial capability). In a different context, studying the social capital and capabilities of ventures, Nahapiet and Ghoshal (1998) and Yli-Renko et al. (2001) posited that capabilities of a venture mediate the relationship between social capital and the core competencies of a firm. This study thus constructs a mediation model that considers the mediate role of a founding team's entrepreneurial capabilities between its networks during creation phase and future spin-off performance; this model is then tested using a bootstrapping technique in the AMOS program. These tests reveal that a standardized direct effect with mediation is insignificant $(-0.047, \mathrm{p}>0.01)$ but that a standardized indirect effect with mediation is significant $(0.122, \mathrm{p}<0.01)$ leading to a conclusion that this new model is a full mediation type (Fig. 3). Therefore, a team's networks during the creation' phase influence its entrepreneurial capabilities which, in turn, enhance spin-off's performance. The results also show that entrepreneurial capability appears to have a significant positive indirect effect on the financial $(0.303, p<0.01)$, operational $(0.435, p<0.01)$, and market performance of spin-offs $(0.355, p<0.01)$ (see table 3$)$.

\section{Insert Table 3 about here.}

All spin-offs in this study were created by academic teams and received support from their universities. Moreover, a spin-off's age, regions and location (within a university incubator) were not found to significantly influence its performance (Table 3). Thus, these control variables do not influence any relationships between dependent and independent variables.

\section{Insert Fig. 3 about here.}

\section{Discussion}


This paper is distinctive in its focus upon university spin-offs and the use of founding teams as the unit of analysis. We posit that spin-offs, through the support of universities, enhance their entrepreneurial capabilities, prior to incorporation, by addressing commercial weaknesses in the academic founding team. This is achieved through the introduction of new team members with more industrial experience and access to a more diverse range of networks. It is suggested that founding teams forged in this way possess capabilities and networks, at incorporation, that imprint themselves upon a spin-off and influence the financial, operational and market performance of spin-offs post incorporation. These hypotheses were tested on survey data from 181 spin-offs in 35 universities in Spain.

Previous literature has identified that university spin-offs originate from non-commercial environments and, as a consequence, exhibit insufficient experience and expertise of business which is integral to their underlying ability to grow (Lockett \& Wright, 2005). In addition, the network quality of academic founders often lacks the breadth and depth of applied industrial or entrepreneurial experience to deliver the requisite capabilities (Jack et al., 2008). TTOs have an important business development role to play, to raise academic founders' awareness of the capabilities required to foster spin-off development and by facilitating access to networks where such capabilities can be obtained. Our evidence suggests that the academic founders of university spin-offs enhance capabilities during the creation phase, with the support of the TTO, by the introduction of personnel with wider industrial experience and more diverse commercial networks. The enhancement and exploitation of networks to access, develop, and integrate new and existing skills assists spinoffs to reconfigure the nature of their capabilities moving on from theoretical technical knowledge to a position where such knowledge can be commercialised.

To enhance commercialisation institutions charged with supporting spin-off activity need to introduce new members into the founding team during the creation phase to enhance commercial skills, build strategic capability and improve the performance of spin-offs (Clarysse \& Moray, 2004; Vohora et al., 2004b; Vanaelst et al., 2006; Bjørnåli \& Aspelund, 2012). While it is recognised that some studies have found that the initial 
resources of a university spin-off quickly dissipate making them less relevant to long-term performance (Shane \& Stuart, 2002), other evidence offered by Kakati (2003) and Aspelund et al. (2005) identifies a more influential and long-term role for the capabilities of founding teams on the performance of spin-offs. This variance is reflected in our own findings. There is good evidence to indicate that the exploitation of capabilities that refer to organisational viability, commercial resource, and technology impact positively upon a university spin-off's performance. However, for other capabilities, the results are more mixed; both human capital and strategy show a negative impact when measured against market performance. This is an unusual finding as it contradicts much of the extant literature and raises some concerns regarding the introduction of experienced entrepreneurs into new ventures. As other writers have suggested, experience, often aligned with age, can increase levels of hubris in entrepreneurs that constrains their motivation to search for new solutions, react to changing markets, and, ultimately, have a negative impact upon the future strategy of the business (Harada, 2003; Ganotakis, 2012). Furthermore, where new members have been introduced with experience of sectors tangential to that of the spin-off, it is possible that any influence on future performance is diluted (Ganotakis, 2012).

We therefore propose that it is in the interest of those involved in university spin-offs to enhance the capabilities of the founding team prior to incorporation and that such activity should be an identified purpose of a university TTO or incubation facility. While the extant literature has focused upon the introduction of individuals with experience of industry, management and entrepreneurship, this research suggests that a more holistic approach is required. Industrial and entrepreneurial capabilities may be limited within the portfolio of academic entrepreneurs, but interventions that simply 'parachute' new members in to address these limitations could exacerbate the issue. The role of the TTO, therefore, is nuanced and they need to find new members that have the requisite sector experience, that remain open to ideas and have an empathy with the academic team that they are joining. Moreover, the TTO must encourage academic entrepreneurs to recognise their limitations and endorse such interventions to facilitate the smooth introduction of new members and get the most out of the combined management team. Outside of this direct intervention, there are clear opportunities to introduce joint 
CPD programmes, internships and secondments throughout the process that supports the application and commercialisation of knowledge. Therefore, this study contributes to our theoretical understanding on why the rate of failure among university spin-offs is still high despite the fact that university TTOs and incubators have attempted to support the creation and development of such ventures.

The hypothesis that the networks of founding teams directly improve performance was not proven with the results providing no clarity as to the direction of the impact across the three variables of structure, governance and content against the three performance measures, finance, operations and market. While there was no evidence of a significant direct relationship between the networks of a founding team and future spin-off performance; an alternative model was constructed in which the entrepreneurial capabilities of a founding team were shown to play a mediate role between networks and a spin-off's performance. In this model founding teams used networks to enhance entrepreneurial capabilities which indirectly led to performance improvements; a point supported by the findings of Jenssen and Koenig (2002), and Vivarelli (2004). It is therefore suggested that the role that networks play in the development of a spin-off is more complex. Prior to incorporation, spinoffs, with the support of TTOs are able to introduce new members to the management team, broaden networks and increase commercial capabilities; all of which have an indirect positive impact upon performance. We argue that these gains are derived from exploitative learning, derived from the experiential knowledge embedded within new team members and easily employed to the benefit of the spin-off. To acquire further benefit requires experimentation, a process of trial and error, which allows for the introduction and removal of connections and a progression of the network. This is outside the scope of this paper but we would suggest it is this process, over time, which creates the more strategic (calculative) networks that shapes spin-off. Thus, we provide support for the perspective that networks, prior to incorporation, offer a positive contribution as they are a source of this experimentation (Grandi \& Grimaldi, 2003; Shane, 2004b; Totterman \& Sten, 2005), but that contribution beyond this is more uncertain and is contingent upon the willingness and ability of founding teams to experiment and explore network boundaries. 
Overall, this paper has demonstrated that the qualities exhibited by the founding teams of university spinoffs at incorporation significantly influence the future development of such ventures and we conclude that the entrepreneurial capabilities and networks of founding teams have direct and indirect influence that contribute to improved spin-off performance. The paper therefore identifies a need to pay more attention to the founding team and the process by which they build capabilities and networks in the ‘creation’ phase. Acknowledging this evidence, it is recommended that universities and policymakers foster networks that integrate academia, entrepreneurs, industry experts, the public sector, and investors. Thus, creating forums to share knowledge and experience, and discuss, identify and exploit solutions for the challenges faced by spin-offs with limited experience or market legitimacy. These points suggest that greater attention should be paid to the way that teams are composed and how they are developed in order to enhance the founders' willingness to interact and communicate among themselves and with external agents.

\section{Conclusion}

There are a number of studies that have sought to understand the contribution of capabilities and networks on start-up performance but the approach this paper takes is distinctive in a number of ways. This research focuses upon university spin-offs, recognised for contexts and attributes that are substantially different from those that exist either in the general start-up population or new technology ventures (Hayter, 2011; Rasmussen et al., 2011; Colombo \& Piva, 2012). In addition, this paper concentrates upon the founding team and evaluates the influence that networks and capabilities, held by the team at incorporation, have upon the future performance of the spin-off. Our arguments therefore assess the degree to which future performance is imprinted, or predicated, upon the capabilities and networks that are gathered round the spin-off, with help from the university TTO, during the creation phase. The use of imprinting theory in this way augments our understanding of the spin-off process and guides future research towards the need to understand the founding team formation, process, and its contributions to the future performance of spin-offs. 
Furthermore, by embedding resource-based view and social network theory into university entrepreneurship studies this paper broadens the contexts in which this relevant theory can be applied. Previous work has highlighted that early stage firm founders are often reluctant to admit the need to expand their capabilities and/or are uncertain about how best to acquire such capabilities (Baker \& Nelson, 2005); often leading to entrepreneurial capacity being constrained (Hughes et al., 2007). To address this issue existing resource-based entrepreneurship studies have focused upon the evolving capabilities of the spin-off (Walter et al., 2006). The findings in this paper identify the important contribution made by a founding team’s capabilities at incorporation; especially those that involve technology, organizational viability and commercial acumen. Acknowledging the role of the founding team at incorporation in the future performance of spin-offs highlights the importance of support during the creation phase, particularly by TTOs, to strengthen networks and enhance capabilities to mitigate against the bespoke liabilities of newness faced by spin-offs. Thus, this paper contributes to our theoretical understanding on the reasons behind the high rates of failure among university spin-offs and the factors and processes that improve the propensity for such ventures to grow.

Finally, we have employed a more detailed measure of spin-off performance to include a three-factor measurement based upon the financial, operational, and market performance of the spin-off. The results of CFA have demonstrated that these measures are statistically valid and reliable, enabling a more fine-grained understanding of what constitutes spin-off performance and reducing the problems researchers often face in obtaining relevant data when requesting financial disclosure.

While the findings from the study are robust, it is acknowledged that there are areas within the research process that could impinge upon the validity and reliability of the work. In comparing the requirement of Structural Equation Modelling, this study’s sample size was restricted because of the limitation on the number of spin-offs from Spanish universities; nevertheless, this sample reflects 21 percent of all spin-offs in Spain between 2003 and 2010. The data was collected using an internet survey which has the potential to be misinterpreted but these issues were carefully explored during the pilot phase of the empirical work. It is also 
possible that respondents to the survey may exhibit a certain cognitive bias based on post-hoc rationalisation.

To address this, the research tested Harman's one-factor on all variables and the result showed that this issue does not affect the overall finding of the study. In addition, this paper employs cross-sectional data to construct a mediation model, it has been suggested that this approach could generate biased estimates because such models ignore the true longitudinal nature of mediation by not allowing statistical control for prior independent or prior dependent variables (Maxwell et al., 2011). We acknowledge this possibility but indicate that such methods have been employed in other non-related works (Chang, 2015; Gkorezis \& Bellou, 2016).

\section{Appendix A.}

\section{Insert Appendix A about here}

\section{Appendix B. Validity and reliability}

\section{Convergent validity}

We construct the CFA of sixteen first-order factors: density, centrality, tie, reputation, reciprocity, trust, information quality, information diversity, technology, organizational viability, human capital, strategy, commercial resource, and financial, operational and market performance. These factors indicate five secondorder variables: structure, governance and content of networks, entrepreneurial capability, and spin-off's performance. The results revealed that both first- and second-order CFA of measurement models are acceptable fit, and each item loads on a single factor and is significant at 0.01 levels (Table B.1).

To assess convergent validity, the extent to which the indicators of measurement converge to a high proportion of variances in common, we examine construct loadings and average variance extracted. The results from the first-order CFA of networks, entrepreneurial capability, and spin-off's performance models reveal that all standardized loadings estimates are higher than 0.5 (Table B.1). Moreover, all indexes of average variance extracted (AVE), the amount of construct variance relative to measurement error, are greater than 0.5 (Table B.2) suggesting adequate convergent validity.

\section{Discriminant validity}

Discriminant validity (i.e., unidimensionality) tests whether a construct is truly distinct from other constructs. The results revealed that all AVE estimates are larger than the corresponding squared interconstruct correlation estimates (SIC) (Table B.2) inferring discriminant validity of the hypothesized structure are supported by our data. 


\section{Reliability}

We compute the composite reliability, analogous to Cronbach's alpha, of all first-order factors by the formula of Fornell and Larcker (1981). Most factors revealed sufficient composite reliabilities (above 0.70) except the reputation factor (0.632) (Table B.2). However, according to Hatcher (1994), the cut-off level of 0.6 is acceptable for a new conceptual variable. Thus, the measurements of this research are reliable.

Insert Table B.1 about here.

Insert Table B.2 about here. 


\section{References}

Agarwal, Madhushree Nanda, \& Chatterjee, Leena. (2007). Entrepreneurial human capital and new venture performance: In search of the elusive link. Academy of Entrepreneurship Journal, 13(1), 1-22.

Aldrich, Howard E., \& Martinez, Martha Argelia. (2001). Many are called, but few are chosen: An evolutionary perspective for the study of entrepreneurship. Entrepreneurship: Theory \& Practice, 25(4), 41.

Amit, R., \& Zott, C. (2001). Value creation in e-business. Strategic Management Journal, 22(6-7), 493-520.

Anderson, J. C., \& Gerbing, D. W. (1988). Structural equation modeling in practice - a review and recomended 2-step approach. Psychol Bull, 103(3), 411-423.

Antoncic, B., \& Hisrich, R. D. (2001). Intrapreneurship: Construct refinement and cross-cultural validation. Journal of Business Venturing, 16(5), 495-527.

Ardichvili, A., Cardozo, R., \& Ray, S. (2003). A theory of entrepreneurial opportunity identification and development. $J$ Bus Ventur, 18(1), 105-123.

Aspelund, Arild, Berg-Utby, Terje, \& Skjevdal, Rune. (2005). Initial resources' influence on new venture survival: A longitudinal study of new technology-based firms. Technovation, 25(11), 1337-1347.

Baker, Ted, \& Nelson, Reed E. (2005). Creating something from nothing: Resource construction through entrepreneurial bricolage. Administrative Science Quarterly, 50(3), 329-366.

Barney, J. (1991). Firm resources and sustained competitive advantage. Journal of Management, 17(1), 99-120.

Barrett, P. (2007). Structural equation modelling: Adjudging model fit. Personality and Individual Differences, 42(5), 815-824.

Bathelt, Harald, Kogler, Dieter F., \& Munro, Andrew K. (2010). A knowledge-based typology of university spin-offs in the context of regional economic development. Technovation, 30(9-10), 519-532.

Berbegal-Mirabent, Jasmina, Lafuente, Esteban, \& Solé, Francesc. (2013). The pursuit of knowledge transfer activities: An efficiency analysis of spanish universities. Journal of Business Research, 66(10), 2051-2059.

Bjørnåli, Ekaterina, \& Aspelund, Arild. (2012). The role of the entrepreneurial team and the board of directors in the internationalization of academic spin-offs. Journal of International Entrepreneurship, 10(4), 350-377.

Boardman, P. Craig, \& Ponomariov, Branco L. (2009). University researchers working with private companies. Technovation, 29(2), 142-153.

Brüderl, Josef, \& Schüssler, Rudolf. (1990). Organizational mortality: The liabilities of newness and adolescence. Administrative Science Quarterly, 35(3), 530-547.

Butler, John E., \& Hansen, Gary S. (1991). Network evolution, entrepreneurial success, and regional development. Entrepreneurship \& Regional Development, 3(1), 1-16.

Byrne, B. (2010). Structural equation modeling with amos: Basic concepts, applications, and programming. NewYork: Routledge.

Campbell, Dennis. (2008). Nonfinancial performance measures and promotion-based incentives. Journal of Accounting Research, 46(2), 297-332.

Chandler, G. N., \& Hanks, S. H. (1993). Measuring the performance of emerging businesses - a validation-study. Journal of Business Venturing, 8(5), 391-408.

Chandler, G. N., \& Jansen, E. (1992). The founders self-assessed competence and venture performance. Journal of Business Venturing, 7(3), 223-236.

Chang, C. H. (2015). Proactive and reactive corporate social responsibility: Antecedent and consequence. Management Decision, 53(2), 451-468.

Clarysse, B., \& Moray, N. (2004). A process study of entrepreneurial team formation: The case of a research-based spinoff. Journal of Business Venturing, 19(1), 55-79.

Clarysse, B., Wright, M., Lockett, A., Mustar, P., \& Knockaert, M. (2007). Academic spin-offs, formal technology transfer and capital raising. Industrial and Corporate Change, 16(4), 609-640.

Colombo, M. G., \& Piva, E. (2012). Firms' genetic characteristics and competence-enlarging strategies: A comparison between academic and non-academic high-tech start-ups. Research Policy, 41(1), 79-92.

Cooper, A.C., \& Daily, C.M. (1997). Entrepreneurial teams. In: Sexton, D.L., Smilor, R.W. editors. Entrepreneurship. Chicago, IL: Upstart Publishing, pp. 127-150.

Covin, J. G., \& Slevin, D. P. (1989). Strategic management of small firms in hostile and benign environments. Strategic Management Journal, 10(1), 75-87.

Deakins, D. (1996). Entrepreneurship and small firms. London: McGrawHill. 
Eisenhardt, K. M., \& Schoonhoven, C. B. (1996). Resource-based view of strategic alliance formation: Strategic and social effects in entrepreneurial firms. Organization Science, 7(2), 136-150.

Eisenhardt, Kathleen. (2013). Top management teams and the performance of entrepreneurial firms. Small Bus Econ, 40(4), 805-816.

Filatotchev, Igor, Toms, Steve, \& Wright, Mike. (2006). The firm's strategic dynamics and corporate governance lifecycle. International Journal of Managerial Finance, 2(4), 256-279.

Fornell, C., \& Larcker, D. F. (1981). Evaluating structural equation models with unobservable variables and measurement error. Journal of Marketing Research, 18(1), 39-50.

Ganco, M., \& Agarwal, R. (2009). Performance differentials between diversifying entrants and entrepreneurial start-ups: A complexity approach. Academy of Management Review, 34(2), 228-252.

Ganotakis, P. (2012). Founders' human capital and the performance of uk new technology based firms. Small Business Economics, 39(2), 495-515.

Garg, V. K., Walters, B. A., \& Priem, R. L. (2003). Chief executive scanning emphases, environmental dynamism, and manufacturing firm performance. Strategic Management Journal, 24(8), 725-744.

Geuna, A., \& Muscio, A. (2009). The governance of university knowledge transfer: A critical review of the literature. Minerva, 47(1), 93-114.

Gimeno, J., Folta, T. B., Cooper, A. C., \& Woo, C. Y. (1997). Survival of the fittest? Entrepreneurial human capital and the persistence of underperforming firms. Administrative Science Quarterly, 42(4), 750-783.

Gkorezis, P., \& Bellou, V. (2016). The relationship between workplace ostracism and information exchange the mediating role of self-serving behavior. Management Decision, 54(3), 700-713.

Gonzalez-Pernia, Jose L., Kuechle, Graciela, \& Pena-Legazkue, Inaki. (2013). An assessment of the determinants of university technology transfer. Economic Development Quarterly, 27(1), 6-17.

Grandi, A., \& Grimaldi, R. (2003). Exploring the networking characteristics of new venture founding teams. Small Business Economics, 21(4), 329-341.

Gupta, Anil K., \& Govindarajan, Vijay. (2000). Knowledge flows within multinational corporations. Strategic Management Journal, 21(4), 473.

Harada, T. (2003). Three steps in knowledge communication: The emergence of knowledge transformers. Research Policy, 32(10), 1737-1751.

Hatcher, L. (1994). A step by step approach to using the sas system for factor analysis and stuctural equation modeling. Cary, NC: SAS Institute Inc.

Hayter, C. S. (2011). In search of the profit-maximizing actor: Motivations and definitions of success from nascent academic entrepreneurs. Journal of Technology Transfer, 36(3), 340-352.

Hayter, C. S. (2013). Harnessing university entrepreneurship for economic growth: Factors of success among university spin-offs. Econ Dev Q, 27(1), 18-28.

Heirman, Ans, \& Clarysse, Bart. (2004). How and why do research-based start-ups differ at founding? A resource-based configurational perspective. The Journal of Technology Transfer, 29(3-4), 247-268.

Helfat, C. E., \& Peteraf, M. A. (2003). The dynamic resource-based view: Capability lifecycles. Strategic Management Journal, 24(10), 997-1010.

Higashide, H., \& Birley, S. (2002). The consequences of conflict between the venture capitalist and the entrepreneurial team in the united kingdom from the perspective of the venture capitalist. Journal of Business Venturing, 17(1), 59-81.

Hite, J. M., \& Hesterly, W. S. (2001). The evolution of firm networks: From emergence to early growth of the firm. Strategic Management Journal, 22(3), 275-286.

Hite, Julie M. (2005). Evolutionary processes and paths of relationally embedded network ties in emerging entrepreneurial firms. Entrepreneurship Theory and Practice, 29(1), 113-144.

Hoang, H., \& Antoncic, B. (2003). Network-based research in entrepreneurship - a critical review. Journal of Business Venturing, 18(2), 165-187.

Hughes, Mathew, Hughes, Paul, \& Morgan, Robert E. (2007). Exploitative learning and entrepreneurial orientation alignment in emerging young firms: Implications for market and response performance. British Journal of Management, 18(4), 359-375.

Huynh, Thanh. (2016). Early-stage fundraising of university spin-offs: A study through demand-site perspectives. Venture Capital, 18(4), 345-367.

Ittner, C. D., \& Larcker, D. F. (2003). Coming up short on nonfinancial performance measurement. Harvard Business Review, 81(11), 88-+. 
Jack, S., Dodd, S. D., \& Anderson, A. R. (2008). Change and the development of entrepreneurial networks over time: A processual perspective. Entrepreneurship and Regional Development, 20(2), 125-159.

Jenssen, J. I., \& Koenig, H. F. (2002). The effect of social networks on resource access and business start-ups. European Planning Studies, 10(8), 1039-1046.

Kakati, M. (2003). Success criteria in high-tech new ventures. Technovation, 23(5), 447.

Kathuria, R. (2000). Competitive priorities and managerial performance: A taxonomy of small manufacturers. Journal of Operations Management, 18(6), 627-641.

Kimberly, J. R. (1979). Issues in the creation of organizations - initiation, innovation, and institutionalization. Academy of Management Journal, 22(3), 437-457.

Kitagawa, Fumi, \& Robertson, Susan. (2012). High-tech entrepreneurial firms in a university-based business incubator. Spaces of knowledge, resource heterogeneity and capital formation. The International Journal of Entrepreneurship and Innovation, 13(4), 249-259.

Leonard-Barton, Dorothy. (1992). Core capabilities and core rigidities: A paradox in managing new product development. Strategic Management Journal, 13, 111-125.

Lockett, A., \& Wright, M. (2005). Resources, capabilities, risk capital and the creation of university spin-out companies. Research Policy, 34(7), 1043-1057.

Lumpkin, G. T., \& Dess, Gregory G. (2001). Linking two dimensions of entrepreneurial orientation to firm performance: The moderating role of environment and industry life cycle. Journal of Business Venturing, 16(5), 429-452.

Lundqvist, Mats A. (2014). The importance of surrogate entrepreneurship for incubated swedish technology ventures. Technovation, 34(2), 93-100.

Markman, Gideon D., Siegel, Donald S., \& Wright, Mike. (2008). Research and technology commercialization. Journal of Management Studies, 45(8), 1401-1423.

Marquis, Christopher, \& Tilcsik, Andras. (2013). Imprinting: Toward a multilevel theory. Academy of Management Annals, 7(1), 195-245.

Marsden, P. V. (1993). The reliability of network density and composition measures. Social Networks, 15(4), 399-421.

Marsden, P. V., \& Campbell, K. E. (1984). Measuring tie strength. Social Forces, 63(2), 482-501.

Mathias, Blake D., Williams, David W., \& Smith, Adam R. (2015). Entrepreneurial inception: The role of imprinting in entrepreneurial action. Journal of Business Venturing, 30(1), 11-28.

Maxwell, Scott E., Cole, David A., \& Mitchell, Melissa A. (2011). Bias in cross-sectional analyses of longitudinal mediation: Partial and complete mediation under an autoregressive model. Multivariate Behavioral Research, 46(5), 816-841.

McGrath, R. G. (1997). A real options logic for initiating technology positioning investments. Academy of Management Review, 22(4), 974-996.

McKelvie, Alexander, \& Davidsson, Per. (2009). From resource base to dynamic capabilities: An investigation of new firms. British Journal of Management, 20, S63-S80.

Milanov, Hana, \& Fernhaber, Stephanie A. (2009). The impact of early imprinting on the evolution of new venture networks. Journal of Business Venturing, 24(1), 46-61.

Miller, N. J., \& Kean, R. C. (1997). Reciprocal exchange in rural communities: Consumers' inducements to inshop. Psychology \& Marketing, 14(7), 637-661.

Mosey, S., \& Wright, M. (2007). From human capital to social capital: A longitudinal study of technology-based academic entrepreneurs. Entrepreneurship Theory and Practice, 31(6), 909-935.

Müller, Kathrin. (2010). Academic spin-off's transfer speed-analyzing the time from leaving university to venture. Research Policy, 39(2), 189-199.

Murphy, G. B., Trailer, J. W., \& Hill, R. C. (1996). Measuring performance in entrepreneurship research. Journal of Business Research, 36(1), 15-23.

Muthen, L. K., \& Muthen, B. O. (2002). How to use a monte carlo study to decide on sample size and determine power. Struct Equ Modeling, 9(4), 599-620.

Nadherny, Christopher C. (1998). Technology and direct marketing leadership. Direct Marketing, 61(7), 42.

Nahapiet, J., \& Ghoshal, S. (1998). Social capital, intellectual capital, and the organizational advantage. Academy of Management Review, 23(2), 242-266.

Newbert, Scott L., \& Tornikoski, Erno T. (2013). Resource acquisition in the emergence phase: Considering the effects of embeddedness and resource dependence. Entrepreneurship Theory and Practice, 37(2), 249-280.

O'Gorman, C., Byrne, O., \& Pandya, D. (2008). How scientists commercialise new knowledge via entrepreneurship. Journal of Technology Transfer, 33(1), 23-43. 
O'Reilly III, Charles A. (1982). Variations in decision makers' use of information sources: The impact of quality and accessibility of information. Academy of Management Journal, 25(4), 756-771.

Parks, M. R., \& Floyd, K. (1996). Meanings for closeness and intimacy in friendship. J Soc Pers Relat, 13(1), 85-107.

Patton, D., \& Marlow, S. (2011). University technology business incubators: Helping new entrepreneurial firms to learn to grow. Environment and Planning C-Government and Policy, 29(5), 911-926.

Ping Jr, Robert A. (2004). On assuring valid measures for theoretical models using survey data. Journal of Business Research, 57(2), 125-141.

Powell, T. C., \& DentMicallef, A. (1997). Information technology as competitive advantage: The role of human, business, and technology resources. Strategic Management Journal, 18(5), 375-405.

Pries, F., \& Guild, P. (2007). Commercial exploitation of new technologies arising from university research: Start-ups and markets for technology. $R$ \& D Management, 37(4), 319-328.

Rasmussen, E., \& Wright, M. (2015). How can universities facilitate academic spin-offs? An entrepreneurial competency perspective. Journal of Technology Transfer, 40(5), 782-799.

Rasmussen, Einar, Mosey, Simon, \& Wright, Mike. (2011). The evolution of entrepreneurial competencies: A longitudinal study of university spin-off venture emergence. Journal of Management Studies, 48(6), 1314-1345.

Rothschild, Leora, \& Darr, Asaf. (2005). Technological incubators and the social construction of innovation networks: An israeli case study. Technovation, 25(1), 59-67.

Rowley, T. J. (1997). Moving beyond dyadic ties: A network theory of stakeholder influences. Academy of Management Review, 22(4), 887-910.

Sapienza, Harry J., Autio, Erkko, George, Gerard, \& Zahra, Shaker A. (2006). A capabilities perspective on the effects of early internationalization on firm survival and growth. Academy of Management Review, 31(4), 914-933.

Shane, S. (2004a). Academic entrepreneurship: University spin-offs and wealth creation. Cheltenham, UK: Edward Elgar.

Shane, S. (2004b). Encouraging university entrepreneurship? The effect of the bayh-dole act on university patenting in the united states. Journal of Business Venturing, 19(1), 127-151.

Shane, S., \& Cable, D. (2002). Network ties, reputation, and the financing of new ventures. Management Science, 48(3), 364-381.

Shane, S., \& Stuart, T. (2002). Organizational endowments and the performance of university start-ups. Management Science, 48(1), 154-170.

Shook, C. L., Ketchen, D. J., Hult, G. T. M., \& Kacmar, K. M. (2004). An assessment of the use of structural equation modeling in strategic management research. Strategic Management Journal, 25(4), 397-404.

Smilor, R. W., Gibson, D. V., \& Dietrich, G. B. (1990). University spin-out companies - technology start-ups from university-of-texas-at-austin. Journal of Business Venturing, 5(1), 63-76.

Soetanto, Danny, \& van Geenhuizen, Marina. (2015). Getting the right balance: University networks' influence on spinoffs' attraction of funding for innovation. Technovation, 36-37(0), 26-38.

Spector, P. E. (1987). Method variance as an artifact in self-reported affect and perceptions at work - myth or significant problem. Journal of Applied Psychology, 72(3), 438-443.

Stinchcombe, A. L. (1965). Social structure and organizations. In: March, J. editor. Handbook of organizations. Chicago, IL: Rand McNally, pp. 142-193.

Tolstoy, Daniel, \& Agndal, Henrik. (2010). Network resource combinations in the international venturing of small biotech firms. Technovation, 30(1), 24-36.

Totterman, H., \& Sten, J. (2005). Start-ups - business incubation and social capital. International Small Business Journal, 23(5), 487-511.

Tsai, W. P., \& Ghoshal, S. (1998). Social capital and value creation: The role of intrafirm networks. Academy of Management Journal, 41(4), 464-476.

Urbano, David, \& Guerrero, Maribel. (2013). Entrepreneurial universities: Socioeconomic impacts of academic entrepreneurship in a european region. Economic Development Quarterly, 27(1), 40-55.

Uzzi, B. (1996). The sources and consequences of embeddedness for the economic performance of organizations: The network effect. American Sociological Review, 61(4), 674-698.

Vanaelst, I., Clarysse, B., Wright, M., Lockett, A., Moray, N., \& S'Jegers, R. (2006). Entrepreneurial team development in academic spinouts: An examination of team heterogeneity. Entrepreneurship Theory and Practice, 30(2), 249271.

Visintin, Francesca, \& Pittino, Daniel. (2014). Founding team composition and early performance of university—based spin-off companies. Technovation, 34(1), 31-43.

Vivarelli, Marco. (2004). Are all the potential entrepreneurs so good? Small Business Economics, 23(1), 41-49. 
Vohora, A., Wright, M., \& Lockett, A. (2004a). Critical junctures in the development of university high-tech spinout companies. Research Policy, 33(1), 147-175.

Vohora, A., Wright, M., \& Lockett, A. (2004b). The formation of high-tech university spinouts through joint ventures. New Technology-Based Firms in the New Millennium, Volume Iii, 101-116.

Walter, Achim, Auer, Michael, \& Ritter, Thomas. (2006). The impact of network capabilities and entrepreneurial orientation on university spin-off performance. Journal of Business Venturing, 21(4), 541-567.

Westerberg, Mats, \& Wincent, Joakim. (2008). Entrepreneur characteristics and management control : Contingency influences on business performance. Journal of business \& entrepreneurship : JBE, 20(1), 37-60.

Wiklund, J., \& Shepherd, D. (2005). Entrepreneurial orientation and small business performance: A configurational approach. Journal of Business Venturing, 20(1), 71-91.

Wiklund, Johan. (1999). The sustainability of the entrepreneurial orientation--performance relationship. Entrepreneurship: Theory \& Practice, 24(1), 39-50.

Witt, Peter. (2004). Entrepreneurs' networks and the success of start-ups. Entrepreneurship \& Regional Development, 16(5), 391-412.

Yli-Renko, H., Autio, E., \& Sapienza, H. J. (2001). Social capital, knowledge acquisition, and knowledge exploitation in young technology-based firms. Strategic Management Journal, 22(6-7), 587-613.

Zahra, S. A. (1993). Environment, corporate entrepreneurship, and financial performance - a taxonomic approach. Journal of Business Venturing, 8(4), 319-340.

Zahra, Shaker A., Van de Velde, Els, \& Larrañeta, Bárbara. (2007). Knowledge conversion capability and the performance of corporate and university spin-offs. Industrial \& Corporate Change, 16(4), 569-608.

Zucker, L. G., Darby, M. R., \& Armstrong, J. S. (2002). Commercializing knowledge: University science, knowledge capture, and firm performance in biotechnology. Management Science, 48(1), 138-153. 


\section{Tables}

Table 1

Descriptive statistics.

\begin{tabular}{|c|c|c|}
\hline Variables & $\mathrm{N}$ & $\%$ \\
\hline \multicolumn{3}{|l|}{ The status of respondents } \\
\hline - $\quad$ Academic founder & 181 & 100 \\
\hline - $\quad$ Non-academic founder & 0 & 0 \\
\hline \multicolumn{3}{|l|}{ Location spin-off created } \\
\hline _ $\quad$ Inside university incubators & 177 & 98 \\
\hline - $\quad$ Outside university incubators & 4 & 2 \\
\hline \multicolumn{3}{|l|}{ Spin-off's creation year } \\
\hline-2011 & 9 & 5 \\
\hline$-\quad 2010$ & 29 & 16 \\
\hline$-\quad 2009$ & 36 & 20 \\
\hline$-\quad 2008$ & 24 & 13 \\
\hline$-\quad 2007$ & 24 & 13 \\
\hline$-\quad 2006$ & 25 & 14 \\
\hline$-\quad 2005$ & 13 & 7 \\
\hline$-\quad 2004$ & 9 & 5 \\
\hline - $\quad$ In and before 2003 & 13 & 7 \\
\hline \multicolumn{3}{|l|}{ Spin-off's industry } \\
\hline - Information, computing and telecommunications & 61 & 33.8 \\
\hline - $\quad$ Engineering and consultancy & 29 & 16.1 \\
\hline - $\quad$ Medicine and health & 28 & 15.3 \\
\hline - $\quad$ Agriculture and biotechnology & 27 & 15 \\
\hline - $\quad$ Energy and environment & 16 & 8.9 \\
\hline - $\quad$ Aeronautics and automotive & 8 & 4.3 \\
\hline - $\quad$ Electronic & 6 & 3.3 \\
\hline - $\quad$ Other industries & 6 & 3.3 \\
\hline \multicolumn{3}{|l|}{ Regions in Spain } \\
\hline - Cataluña & 76 & 42.0 \\
\hline - Andalucía & 36 & 19.9 \\
\hline - Valencia & 33 & 18.2 \\
\hline - Castilla \& León & 16 & 8.8 \\
\hline - $\quad$ Madrid & 10 & 5.5 \\
\hline - $\quad$ Other communities & 10 & 5.5 \\
\hline
\end{tabular}

Table 2

Linear regression models.

\begin{tabular}{|c|c|c|c|c|c|c|}
\hline \multirow{2}{*}{ Variables } & \multicolumn{2}{|c|}{ Financial performance } & \multicolumn{2}{|c|}{ Operational performance } & \multicolumn{2}{|c|}{ Market performance } \\
\hline & Model 1 & Model 2 & Model 3 & Model 4 & Model 5 & Model 6 \\
\hline Network structure & $-0.402 *$ & $-0.428 *$ & -0.216 & $-0.111 * *$ & -0.149 & \\
\hline Network governance & 0.067 & & 0.052 & & -0.084 & \\
\hline Network content & $0.496^{*}$ & $0.578 * *$ & 0.072 & & 0.203 & \\
\hline Technology & -0.085 & & $0.154 * * *$ & $0.141^{* * *}$ & 0.052 & \\
\hline Organizational viability & 0.159 & & $0.166^{*}$ & & $0.279 * * *$ & $0.274^{* * *}$ \\
\hline Human capital & -0.034 & & -0.048 & & $-0.093 * *$ & $-0.097 * * *$ \\
\hline Strategy & -0.016 & & -0.148 & & $0.310 * *$ & $-0.274 * *$ \\
\hline Commercial resource & $0.176^{* *}$ & $0.180 * * * *$ & $0.168^{* * *}$ & $0.153^{* * * *}$ & $0.245 * * * *$ & $0.260 * * * *$ \\
\hline \multicolumn{7}{|l|}{ Control } \\
\hline Spin-off's age & 0.002 & 0.006 & 0.006 & -0.005 & -0.023 & -0.024 \\
\hline Within incubator & 0.052 & 0.060 & 0.038 & 0.044 & 0.058 & 0.075 \\
\hline
\end{tabular}




\begin{tabular}{|c|c|c|c|c|c|c|}
\hline Cataluña & 0.167 & 0.072 & -0.298 & $-0.317^{*}$ & -0.235 & $-0.203-0.347$ \\
\hline Andalucía & 0.099 & 0.027 & -0.315 & -0.325 & -0.370 & -0.203 \\
\hline Valencia & 0.009 & -0.051 & $-0.420 * *$ & $-0.412 * *$ & -0.222 & -0.383 \\
\hline Castilla \& León & 0.060 & 0.036 & -0.342 & -0.323 & -0.410 & -0.109 \\
\hline Madrid & 0.219 & 0.177 & -0.287 & -0.290 & -0.120 & \\
\hline $\mathrm{R}^{2}$ & 0.231 & 0.208 & 0.340 & 0.318 & 0.269 & $\begin{array}{l}0.261 \\
0.213\end{array}$ \\
\hline Adjusted $\mathrm{R}^{2}$ & 0.161 & 0.162 & 0.280 & 0.278 & 0.203 & $5.423 * * * *$ \\
\hline $\mathrm{F}$ & $3.299 * * * *$ & $4.475 * * * *$ & $5.674 * * * *$ & $7.938 * * * *$ & $0.049 * * * *$ & \\
\hline
\end{tabular}

\section{Table 3}

Path analysis results: Direct and indirect effects.

\begin{tabular}{|c|c|c|}
\hline Paths & $\begin{array}{l}\text { Standardised } \\
\text { direct effects }\end{array}$ & $\begin{array}{l}\text { Standardised } \\
\text { indirect effects }\end{array}$ \\
\hline Network $\rightarrow$ Entrepreneurial capability & $0.340 * *$ & \\
\hline Network $\rightarrow$ Spin-off's performance & -0.081 & \\
\hline Entrepreneurial capability $\rightarrow$ Spin-off's performance & $0.466^{* *}$ & \\
\hline Network $\rightarrow$ Spin-off's performance & & $0.158 * *$ \\
\hline Entrepreneurial capability $\rightarrow$ Financial performance & & $0.303 * *$ \\
\hline Entrepreneurial capability $\rightarrow$ Operational performance & & $0.435 * *$ \\
\hline Entrepreneurial capability $\rightarrow$ Market performance & & $0.355 * *$ \\
\hline Network $\rightarrow$ Entrepreneurial technology & & $0.232 * *$ \\
\hline Network $\rightarrow$ Organizational viability & & $0.322 * *$ \\
\hline Network $\rightarrow$ Human capital & & $0.099 * *$ \\
\hline Network $\rightarrow$ Strategy & & $0.297 * *$ \\
\hline Network $\rightarrow$ Commercial resource & & $0.285 * *$ \\
\hline \multicolumn{3}{|l|}{ Control } \\
\hline Spin-off’s age $\rightarrow$ Spin-off’s performance & 0.012 & \\
\hline Within incubator $\rightarrow$ Spin-off's performance & 0.089 & \\
\hline Cataluña $\rightarrow$ Spin-off’s performance & -0.113 & \\
\hline Andalucía $\rightarrow$ Spin-off's performance & -0.184 & \\
\hline Valencia $\rightarrow$ Spin-off’s performance & -0.184 & \\
\hline Castilla \& León $\rightarrow$ Spin-off's performance & -0.123 & \\
\hline Madrid $\rightarrow$ Spin-off's performance & -0.057 & \\
\hline
\end{tabular}

** denotes $p<0.01$; Two Tailed significance. 
Appendix A. Means, standard deviations, ranges, and correlations for variables in the measurement model

\begin{tabular}{|c|c|c|c|c|c|c|c|c|c|c|c|}
\hline \multicolumn{12}{|c|}{ Variables } \\
\hline & 1 & 2 & 3 & 4 & 5 & 6 & 7 & 8 & 9 & 10 & 11 \\
\hline \multicolumn{12}{|l|}{ (1) Network structure } \\
\hline (2) Network governance & $.762 * *$ & & & & & & & & & & \\
\hline (3) Network content & $.944 * *$ & $.778 * *$ & & & & & & & & & \\
\hline (4) Technology & $.173 *$ & $.203 * *$ & $.196 * *$ & & & & & & & & \\
\hline (5) Organizational viability & $.314^{* *}$ & $.302 * *$ & $.358 * *$ & $.388 * *$ & & & & & & & \\
\hline (6) Human capital & $.160^{*}$ & $.199 * *$ & $.156^{*}$ & $.190 * *$ & $.393 * *$ & & & & & & \\
\hline (7) Strategy & $.242 * *$ & $.239 * *$ & $.278 * *$ & $.589 * *$ & $.835 * *$ & $.289 * *$ & & & & & \\
\hline (8) Commercial resource & $.183^{*}$ & $.160 *$ & $.215^{* *}$ & $.553 * *$ & $.558 * *$ & $.333^{* *}$ & $.729 * *$ & & & & \\
\hline (9) Financial performance & .129 & .139 & $.186^{*}$ & $.163 *$ & $.308 * *$ & .130 & $.320 * *$ & $.329 * *$ & & & \\
\hline (10) Operational performance & -.040 & -.004 & -.001 & $.419 * *$ & $.307^{* *}$ & .101 & $.384 * *$ & $.446^{* *}$ & $.368 * *$ & & \\
\hline (11) Market performance & .064 & .044 & .102 & $.233^{* *}$ & $.256^{* *}$ & .033 & $.262^{* *}$ & $.368 * *$ & $.494^{* *}$ & $.722 * *$ & \\
\hline Mean & 4.31 & 3.72 & 4.51 & 5.58 & 5.76 & 5.10 & 5.15 & 5.63 & 3.34 & 3.78 & 4.63 \\
\hline S.D. & 0.77 & 0.48 & 0.76 & 1.134 & 0.97 & 1.50 & 0.90 & 1.25 & 0.87 & 0.64 & 7.34 \\
\hline Min. & 1.543 & 1.911 & 1.892 & 1.775 & 2.428 & 1.660 & 1.669 & 1.626 & 0.907 & 1.450 & 5.965 \\
\hline Max. & 5.667 & 4.429 & 5.797 & 7.316 & 7.532 & 8.252 & 6.810 & 8.055 & 5.568 & 4.831 & 1.719 \\
\hline
\end{tabular}

*. Correlation is significant at the 0.05 level (2-tailed).

**. Correlation is significant at the 0.01 level (2-tailed). 


\section{Table B.1}

Factor loading of CFA.

A founder's assessment of the networks available to a spin-off at the end of the creation phase based upon the evaluation of the following statements that report the relationships between your team and individuals from whom you have received advice or information (1: Strongly disagree...7: Strongly agree).

\begin{tabular}{|c|c|c|c|}
\hline & Measures & $\begin{array}{l}\text { First order } \\
\text { loadings }\end{array}$ & $\begin{array}{l}\text { Second } \\
\text { order } \\
\text { loadings }\end{array}$ \\
\hline \multicolumn{4}{|l|}{ Structure } \\
\hline \multirow[t]{4}{*}{ Density } & & & $0.769 * *$ \\
\hline & Knowing each other by name & $0.688 * *$ & \\
\hline & Talking to each other about business & $0.941 * *$ & \\
\hline & Seeing each other regularly in business situations & $0.933 * *$ & \\
\hline \multirow[t]{5}{*}{ Centrality } & & & $0.797 * *$ \\
\hline & We talked directly about business issues & $0.67^{* *}$ & \\
\hline & We received directly helpful business information & $0.712^{* *}$ & \\
\hline & We could call for advice about running our business & $0.697 * *$ & \\
\hline & We were the first to receive new things in the group & $0.781 * *$ & \\
\hline \multirow[t]{4}{*}{ Ties } & & & $0.681 *$ \\
\hline & We would share personal matters with them & $0.663^{* *}$ & \\
\hline & We might discuss family matters with them & $0.917^{* *}$ & \\
\hline & We might ask them for advice about private matter & $0.832 * *$ & \\
\hline \multicolumn{4}{|c|}{ 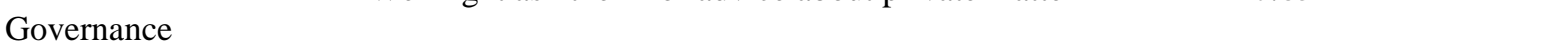 } \\
\hline \multirow[t]{5}{*}{ Reputation } & & & $0.627 * *$ \\
\hline & We generated a lot of enthusiasm & $0.711^{* *}$ & \\
\hline & We had a forgiving nature & $0.604 * *$ & \\
\hline & We persevered until the task is finished & $0.742 * *$ & \\
\hline & We liked to play with ideas & $0.775^{* *}$ & \\
\hline \multirow[t]{5}{*}{ Reciprocity } & & & $0.755^{* *}$ \\
\hline & People were generally pair in dealings with us & $0.759 * *$ & \\
\hline & People were willing to do us a favour if asked & $0.598 * *$ & \\
\hline & We did favours for each other from time to time & $0.762 * *$ & \\
\hline & People patronized my business & $0.87 * *$ & \\
\hline \multirow{4}{*}{ Trust } & & & $0.826 * *$ \\
\hline & We were dependable by these people & $0.888 * *$ & \\
\hline & People would say that we are sincere & $0.917 * *$ & \\
\hline & They would say that we are trustworthy & $0.604 * *$ & \\
\hline \multicolumn{4}{|c|}{ 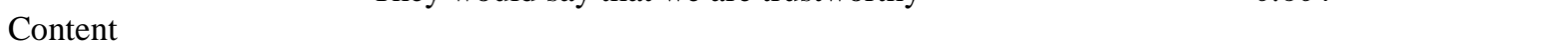 } \\
\hline \multirow[t]{4}{*}{ Information quality } & Their information was usually accurate & $0.878 * *$ & \\
\hline & Their information was relevant & $0.916^{* *}$ & \\
\hline & Their information was specific & $0.859 * *$ & \\
\hline & I quickly received their information & $0.777^{* *}$ & \\
\hline \multirow{5}{*}{$\begin{array}{l}\text { Diversity information } \\
\text { (information used to be } \\
\text { exchanged) }\end{array}$} & Market data & $0.782 * *$ & \\
\hline & Product design & $0.913^{* *}$ & \\
\hline & Process design & $0.854 * *$ & \\
\hline & Marketing know-how & $0.75^{* *}$ & \\
\hline & Packaging design/technology & $0.744 * *$ & \\
\hline
\end{tabular}

- Structure model (CMIN/DF=1.269, RMSEA=0.039, NFI=0.961, CFI=0.991, GFI=0.964).

- Governance model $(C M I N / D F=1.149, R M S E A=0.029, N F I=0.950, C F I=0.993$, GFI=0.963).

- Content model (CMIN/DF=1.288, RMSEA=0.040, NFI=0.973, CFI=0.994, GFI=0.965).

* Loading significant at the 0.05 level. ** Loading significant at the 0.01 level. ${ }^{\text {* }}$ Scaled 1: Not at all, 7: Very much. 


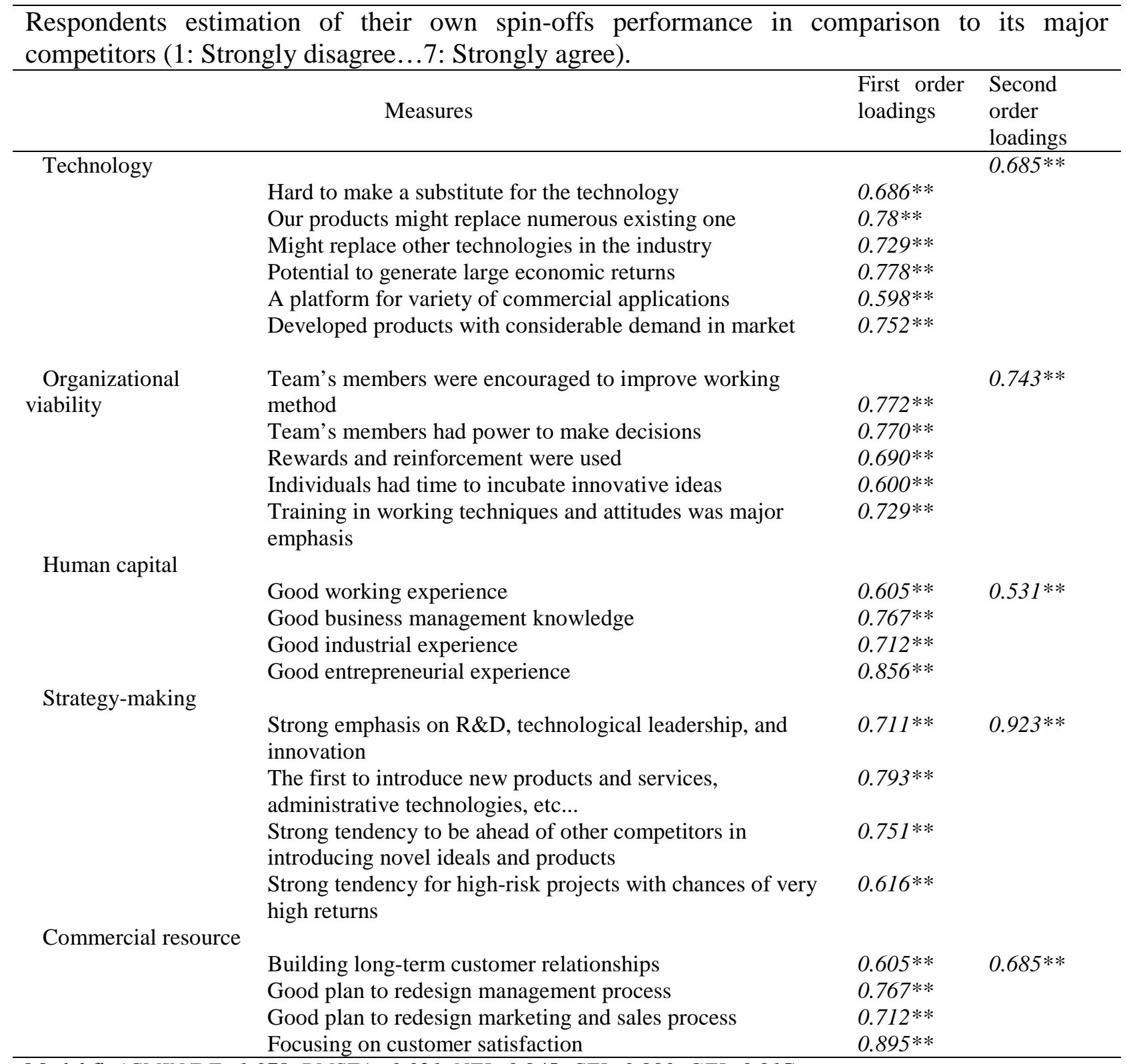

Model fit (CMIN/DF=1.078, RMSEA=0.021, NFI=0.945, CFI=0.990, GFI=0.915).

* Loading significant at the 0.05 level. ** Loading significant at the 0.01 level.

\begin{tabular}{llrl}
\hline $\begin{array}{l}\text { Describing the current performance of spin-off compared to its major competitors (1: Much } \\
\text { lower...7: Much higher). }\end{array}$ \\
\hline \multicolumn{1}{c}{ Measures } & $\begin{array}{l}\text { First order } \\
\text { loadings }\end{array}$ & $\begin{array}{l}\text { Second } \\
\text { order } \\
\text { loadings }\end{array}$ \\
\hline Financial performance & Sales growth & $0.854^{* *}$ & $0.564^{* *}$ \\
& Revenue growth & $0.936^{* *}$ & \\
Net profit margin & $0.693^{* *}$ & $0.666^{* *}$ \\
Operational & Product/ service innovation & $0.753^{* *}$ & \\
performance & Process of innovation & $0.730^{* *}$ & $0.721^{* *}$ \\
Market performance & Adaptation of new technology & $0.915^{* *}$ \\
& Product/service quality & $0.722^{* *}$ & \\
\hline
\end{tabular}




\begin{tabular}{cc}
\hline Product/service variety & $0.697^{* *}$ \\
Customer satisfaction & $0.735^{* *}$ \\
\hline
\end{tabular}

Model fit $(C M I N / D F=1.416, R M S E A=0.048, N F I=0.946, C F I=0.980, G F I=0.961)$.

* Loading significant at the 0.05 level; ** Loading significant at the 0.01 level.

Table B.2

Reliability and validity tests.

\begin{tabular}{cccc}
$\begin{array}{c}\text { Construct } \\
\text { reliability (CR) }\end{array}$ & $\begin{array}{c}\text { Composite } \\
\text { reliability }^{\text {a }}\end{array}$ & $\begin{array}{c}\text { Average variance } \\
\text { extracted (AVE) }\end{array}$ & $\begin{array}{c}\text { Squared } \\
\text { interconstruct } \\
\text { correlation (SIC) }\end{array}$ \\
\hline
\end{tabular}

\begin{tabular}{|c|c|c|c|c|}
\hline \multicolumn{5}{|l|}{ Network } \\
\hline Structure & 0.7940 & & 0.5634 & \\
\hline Density & 0.8949 & 0.888 & 0.7431 & $0.0751 ; 0.2025$ \\
\hline Centrality & 0.8076 & 0.736 & 0.5129 & $0.1475 ; 0.2052$ \\
\hline Ties & 0.8499 & 0.840 & 0.6576 & $0.0751 ; 0.1475$ \\
\hline Governance & 0.7825 & & 0.5485 & \\
\hline Reputation & 0.8020 & 0.632 & 0.5054 & $0.1043 ; 0.1246$ \\
\hline Reciprocity & 0.8379 & 0.850 & 0.5678 & $0.1043 ; 0.3894$ \\
\hline Trust & 0.8523 & 0.879 & 0.6647 & $0.1246 ; 0.3894$ \\
\hline Content & 0.7220 & & 0.5650 & \\
\hline Information quality & 0.9182 & 0.926 & 0.7379 & 0.2767 \\
\hline Diversity of information & 0.9053 & 0.922 & 0.6580 & 0.2767 \\
\hline Entrepreneurial capability & 0.8427 & & 0.5249 & \\
\hline Technology & 0.8668 & 0.839 & 0.5221 & $0.3204 ; 0.2927$ \\
\hline Organizational viability & 0.8384 & 0.794 & 0.5113 & $0.1069 ; 0.5083$ \\
\hline Human capital & 0.8279 & 0.808 & 0.5498 & $0.0320 ; 0.1069$ \\
\hline Strategy & 0.8109 & 0.702 & 0.5195 & $0.0600 ; 0.5083$ \\
\hline Commercial resource & 0.8135 & 0.708 & 0.5226 & $0.0841 ; 0.3881$ \\
\hline Spin-off's performance & 0.7666 & & 0.5326 & \\
\hline Financial performance & 0.8557 & 0.842 & 0.6049 & $0.0955 ; 0.1806$ \\
\hline Operational performance & 0.7787 & 0.709 & 0.5399 & $0.0955 ; 0.3709$ \\
\hline Market performance & 0.7616 & 0.712 & 0.5158 & $0.1806 ; 0.3709$ \\
\hline
\end{tabular}

${ }^{\text {a }}$ Analogous to Cronbach's Alpha. 
Figures

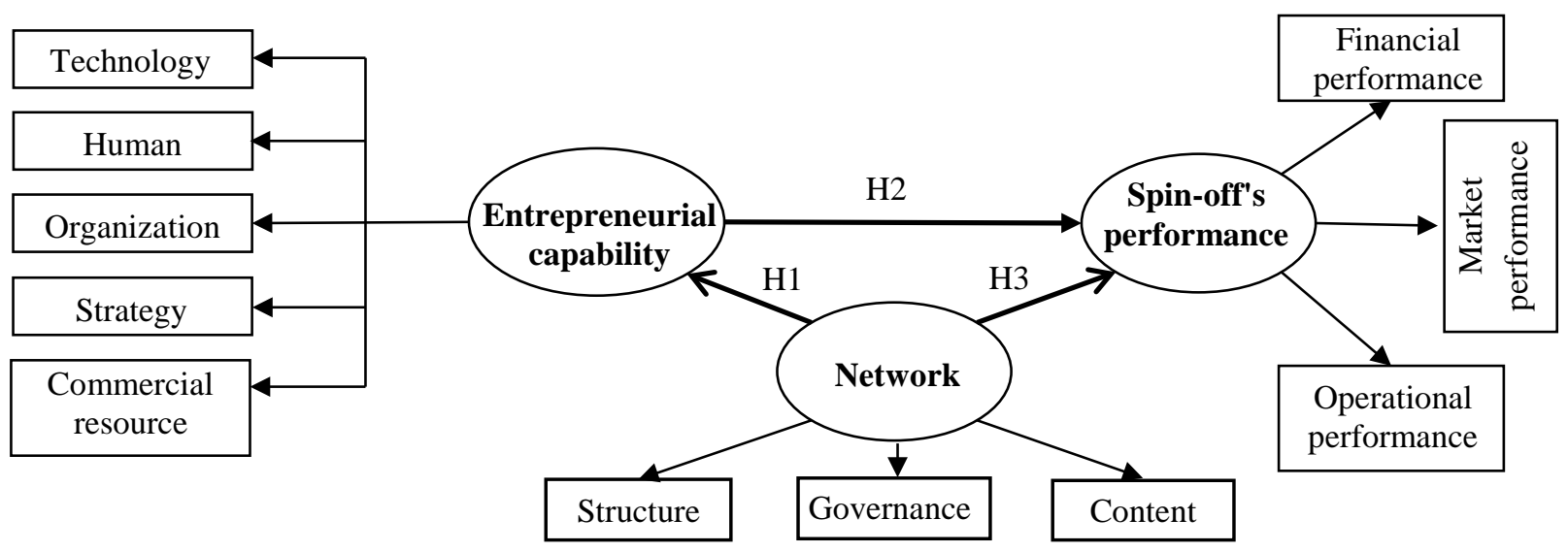

Fig. 1. Conceptual model.

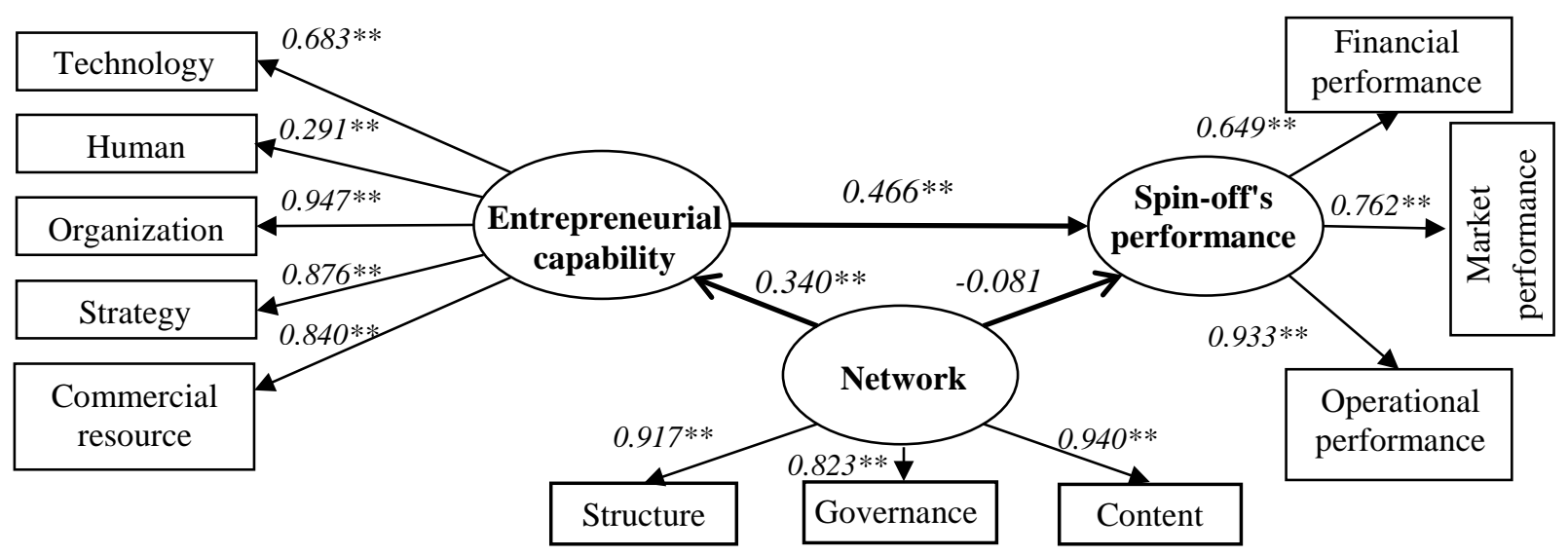

Fig. 2. Hypothesized model (** denotes $\mathrm{p}<0.01$, all error terms omitted for clarity) (Model Fit: CMIN/DF=1.595, RMSEA=0.057, NFI=0.910, CFI=0.931, GFI=0.918). 


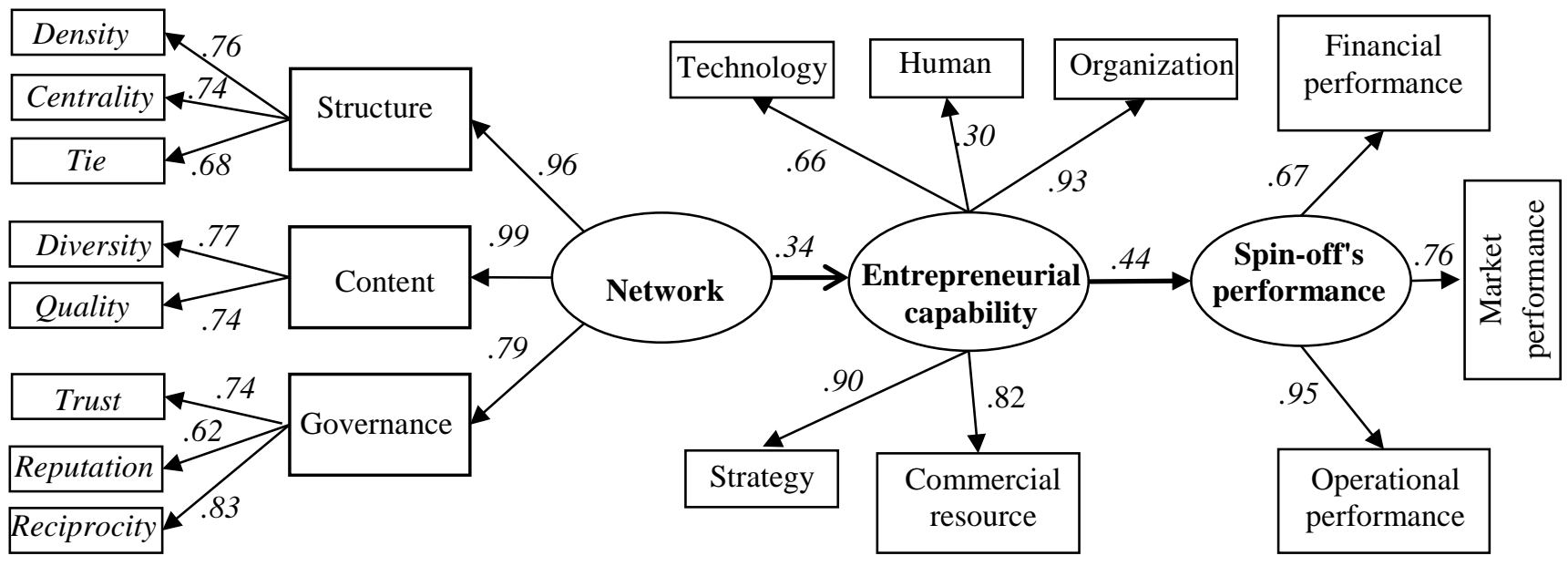

Fig. 3. Mediation model (All estimates are significant at the 0.01 level, all error terms omitted for clarity) (Model Fit: CMIN/DF=1.576, RMSEA=0.057, NFI=0.960, CFI=0.985, and GFI=0.948). 